\title{
1 The evolution of the Dogger Bank, North Sea: a 2 complex history of terrestrial, glacial and marine 3 environmental change
}

4 Carol J. Cotterill ${ }^{1}$, Emrys Phillips ${ }^{1}$, Leo James ${ }^{2}$, Carl Fredrik Forsberg ${ }^{3}$, Tor Inge Tjelta ${ }^{4}$, Gareth

5 Carter $^{1}$ and Dayton Dove ${ }^{1}$

6 1. British Geological Survey, The Lyell Centre, Research Avenue South, Edinburgh EH14 4AP, UK

7 2. RPS Energy Ltd, Goldvale House, 27-41 Church Street West, Woking, Surrey, GU21 6DH

8 3. $\mathrm{NGI}$, Sognsveien $72, \mathrm{~N}-0855$ Oslo, Norway

9 4. Statoil, Forusbeen 50, 4035 Stavanger, Norway

Corresponding Author-cjcott@bgs.ac.uk

\section{Abstract}

12 This paper presents a summary of the results of a detailed multidisciplinary study of the near surface geology of the Dogger Bank in the southern central North Sea, forming part of a site investigation for a major windfarm development undertaken by the Forewind consortium. It has revealed that the Dogger Bank is internally complex rather than comprising a simple "layer cake" of the Quaternary sediments as previously thought. Regional and high-resolution seismic surveys have enabled a revised stratigraphic framework to be established for the upper part of this sequence which comprises the Eem (oldest), Dogger Bank, Bolders Bank formations, Volans Member and Botney Cut Formation (youngest), overlain by a typically thin Holocene sequence. Detailed mapping of key horizons identified on the high-resolution seismic profiles has led to the recognition of a series of buried palaeo-landsystems which are characterised by a range of features including; glacial, glacifluvial and fluvial channels, a large-scale glacitectonic thrust-moraine complex with intervening ice-marginal basins, a lacustrine basin and marine ravinement surfaces. Interpretation of these buried landscapes has enabled the development of an environmental change model to explain the evolution of the Dogger Bank. This evolution was driven by the complex interplay between climate change, ice sheet dynamics and sea level change associated with the growth and subsequent demise of the British and Irish and Fennoscandian ice sheets during the Weichselian glaciation. Following the decay of these ice sheets the Dogger Bank entered a period of significant climatic and environmental 
flux which saw a terrestrial landscape being progressively inundated as sea levels rose during the Holocene.

Keywords - Dogger Bank; North Sea; stratigraphy; 2D seismic data; glacial and marine environmental change

\section{Highlights}

- Detailed multidisciplinary study of the Quaternary of the Dogger Bank, North Sea

- A revised stratigraphic framework of the Dogger Bank has been established

- A number of buried, terrestrial palaeo-landscapes have been identified

- A model involving ice sheet dynamics, climate and sea level change is proposed

\section{Introduction}

The North Sea has had a long and complex geological history with its present-day structural configuration largely being the result of rifting during the Jurassic-Early Cretaceous, followed by thermal cooling and subsidence (Glennie and Underhill, 1998; Zanella and Coward, 2003). Since the middle Cenozoic, up to $3000 \mathrm{~m}$ of Oligocene to Holocene sediments have accumulated in the central graben region of the North Sea, locally including more than $800 \mathrm{~m}$ of Quaternary sediments (Caston, 1977, 1979; Gatliff et al., 1994). Preserved within this sedimentary record is the evidence for several ice sheets having advanced into the North Sea at different stages during the Quaternary, contributing to the periodic erosion and infill of this sedimentary basin. The traditional view of the Pleistocene glacial history of the North Sea suggests that the region has encountered three major glacial episodes during the past $500 \mathrm{ka}$, referred to as the Elsterian Stage (oldest, Marine Isotope Stage [MIS] 12), Saalian Stage (MIS 10-6), and Weichselian Stage (youngest, MIS 5d-2) glaciations (Eisma et al., 1979; Jansen et al., 1979; Caston 1979; Balson and Cameron, 1985; Sejrup et al., 1987, 1995, 2000, 2003; Cameron et al., 1987; Ehlers, 1990; Cameron et al., 1992; Graham et al., 2007, 2011; Kristensen et al., 2007; Bradwell et al., 2008; Stoker et al., 2011; Stewart et al., 2013; Ottesen et al., 2014). The main criterion for this threefold subdivision are the discrete sets of tunnel valleys preserved offshore, which delimit the broad extents and submarginal drainage systems developed beneath these ice sheets during each phase of glaciation (Wingfield, 1990; Huuse et al., 2001; Praeg, 2003; Lonergan et al., 2006; Kristensen et al., 2007; Stewart and Lonergan, 2011; Stewart et al., 2013). However, in recent years, this simple three-stage model has come under considerable scrutiny and there is now growing body of evidence that there may have been many more glacial episodes (e.g. Lonergan et al., 2006; Stewart and Lonergan, 2011). The increasing geomorphological evidence for ice sheets having extended across the northwest European continental shelves 
(Graham et al., 2007, 2011; Bradwell et al., 2008), means that it is becoming increasingly apparent that the sedimentary record within the North Sea Basin is likely to contain the key evidence for the existence of these former Pleistocene ice sheets and intervening interglacials. Furthermore, the North Sea Basin is known to have been an important pathway for large-scale glacial transport to the deeper Atlantic Ocean, as shown by the presence of large glacial debris fans along the northwest European continental margin. These fans were fed by ice streams, comparable with those that drain the majority of ice from modern-day Greenland and Antarctica, and these were probably a key feature of the North Sea ice sheets. As a result, the North Sea Basin is an important site for understanding the discharge and stability of the major northern European palaeo-ice masses, including the British and Irish and Fennoscandian ice sheets.

A number of the current models for the Weichselian Stage glaciation of the North Sea (Graham et al., 2007, 2011; Bradwell et al., 2008; Sejrup et al., 2009) require the British and Irish and Fennoscandian ice sheets to have converged forming a "confluence zone" within the central part of the basin located to the north of, and between Dogger Bank and Denmark. However, the actual limits of these major ice masses within the southern North Sea are poorly understood and constrained (Catt, 1991; Sejrup et al., 2009). Consequently, establishing a robust model for the evolution of the Dogger Bank is critical to our understanding ice sheet dynamics in the southern central North Sea. However, until recently, very little was known about the sedimentary and structural architecture of the Quaternary and Holocene sediments of the Dogger Bank region.

In 2008 The Crown Estate identified nine potential development zones for Round 3 windfarm development. In response to this call, RWE Npower Renewables, SSE, Statoil and Statkraft formed a consortium (Forewind) with a view to developing part of the Dogger Bank area (referred to as the Dogger Bank Zone) of the central North Sea (Figure 1). The Dogger Bank lies in an area of shallow water approximately $100 \mathrm{~km}$ wide by $250 \mathrm{~km}$ long, and whilst the majority of the bank falls within the UK sector of the North Sea (Figure 1a), it also extends into Dutch and German territorial waters. The Dogger Bank Zone (DBZ) is situated 125 to $290 \mathrm{~km}$ northeast of Yorkshire coast and is the largest of the Round 3 zones, covering an area of $8660 \mathrm{~km}^{2}$, with water depths ranging from 18 to $63 \mathrm{~m}$ Lowest Astronomical Tide (LAT). The Round 3 Zone covers the central and northern parts of the Dogger Bank, and is located entirely within the UK sector (Figure 1b). The lack of understanding regarding the sedimentary and structural architecture of the Quaternary and Holocene sediments on Dogger Bank represented a major issue for the development of a windfarm in the DBZ. The stratigraphy and structure of the Dogger Bank was believed to be a relatively simple "layer-cake" with much of the upper $60 \mathrm{~m}$ (the foundation depth for the windfarm) of this unconsolidated 
sedimentary sequence being assigned to the Dogger Bank Formation (Balson and Cameron, 1985; Cameron et al., 1992). However, the acquisition of high-resolution data during the site investigation of the DBZ has proven that this is far from the case. This paper presents a summary of the results of the detailed multidisciplinary study undertaken by scientists from the Forewind consortium, the British Geological Survey and academia. Regional and high-resolution seismic survey data acquired during the site investigation are used to provide an updated interpretation of the stratigraphy of the DBZ, allowing the formulation of a robust palaeoenvironmental model which for the first time describes the evolution of this poorly understood region.

\section{Regional setting and previous research}

Dogger Bank is an isolated topographic high in the centre of the North Sea (Figure 1a), and forms part of a sedimentary basin that has experienced long periods of rifting, sedimentation and glaciations over the last 300 million years. These processes have fundamentally influenced the nature, sedimentary architecture and geotechnical properties of the seabed and sub-seabed. It is well-established that much of the floor of the North Sea had been profoundly modified during the last Weichselian (Devensian) glaciation (Eisma et al., 1979), with the earlier Quaternary history of sedimentation having also been controlled by alternating glacial and interglacial conditions, with the associated sea level fluctuations (Jansen et al., 1979). However, Caston (1979) demonstrated that a significant thickness of Quaternary deposits throughout the North Sea Basin had accumulated through tectonic subsidence. Subsequent geological mapping in the southern North Sea has shown that the majority of the deposits are in fact early to middle Quaternary in age, and deposited in shallow water, distal and deltaic environments (Balson and Cameron, 1985). These sediments represent the continuation of a major delta system that extended into the area from the Netherlands which was fed not only by the Rhine but also several major rivers draining catchments in the area of the Baltic. These major fluvial systems eventually merged with smaller river systems flowing eastwards from the UK (Zagwijn 1989, p. 114; Zagwijn and Doppert 1978) in what is now the southern and central North Sea Basin. It was only during the middle to Late Quaternary that ice sheets eventually encroached into the southern part of the North Sea leading to deposition of locally thick sequences of proglacial and subglacial sediments. In the DBZ, Quaternary sediments can be up to $800 \mathrm{~m}$ thick - one of the thickest occurrences in the North Sea, comprising a mix of glacial, deltaic and shallow marine deposits. 
The Quaternary Era represents a period of considerable global climatic instability, with repeated cycles of climate change. The base of the Quaternary is currently considered to occur at 2.6 Ma (http://www.geosociety.org/science/timescale/timescl.pdf), coinciding with a major change in the fauna of northwestern Europe which is considered to be the first signal in Europe of a major global cooling event. In the Dutch sector of the Dogger Bank, iceberg scars and palaeontological provide evidence for the presence of sea-ice dating back to about 2.2 Ma (Kuhlmann and Wong, 2008).

Regional mapping of the North Sea basin, completed by the late 1980's and early 1990's (BGS 1989, 1991; Cameron et al., 1992), led to the recognition that the Quaternary geology of the Dogger Bank comprises a series of marine - intertidal - proglacial - subglacial - marine cycles, which record significant climatic changes during this period. Furthermore these cycles provide the key evidence for the influence of three main glaciations within the North Sea Basin; namely the Elsterian, Saalian and Weichselian. Onshore the subdivision of the Quaternary is based upon lithostratigraphic and biostratigraphic evidence, whilst offshore the stratigraphy is based on seismostratigraphic principals. Consequently a different set of names has been adopted for the main units (Table 1). Stoker et al. (2011) divided the entire Quaternary succession in the southern North Sea into three major groups:

1. Southern North Sea Deltaic Group (oldest) ranging in age from Lower Pleistocene to Lower However detailed information regarding the nature of the Dogger Bank Formation was rather limited. Until recently the formation was described as a tabular unit, up to $45 \mathrm{~m}$ thick comprising locally stratified to well-bedded sediments which were thought to have been deposited in proglacial or glaciolacustrine setting. Cameron et al. (1992) suggested that the Dogger Bank was formed through either deposition in an ice-dammed lake environment, or within a standing body of water trapped along the confluence of two large ice sheets; namely British and Irish Ice Sheet (BIIS) and Fennoscandian Ice Sheet (FIS). Due to the lack of boreholes (other than $6 \mathrm{~m}$ deep vibrocores) and limited commercial investigation in the Dogger Bank area the stratigraphic sequence proposed by British Geological Survey (Cameron et al., 1992) for the region relied heavily on the extrapolation of seismic stratigraphies from adjacent areas. In 2008 the British Geological Survey (BGS) and Centre for Environment, Fisheries and Aquaculture Science (Cefas) were commissioned by the Joint Nature Conservation Committee (JNCC) to characterise the seabed with respect to biological communities 
(Diesing et al., 2009), adding detail to our understanding of seabed sediment distribution and bedforms on a portion of Dogger Bank. However this study did not include a revision of the subsurface geology and/or stratigraphy.

Consequently very little was known about the character of the upper $60 \mathrm{~m}$ of sediments on Dogger Bank; a major issue for the development of a windfarm in the DBZ. The present multidisciplinary study, a collaborative venture between scientists from the Forewind consortium, the BGS and academia, addresses this lack of understanding. Regional and high-resolution seismic survey data acquired for during the study have led to an updated interpretation of the stratigraphy of the DBZ. This has allowed the development of a robust palaeoenvironmental model which for the first time describes the evolution of the Dogger Bank; a complex history driven by the interplay between global climate change, ice sheet dynamics and sea level fluctuations accompanying the growth and subsequent demise of two major ice sheets.

\section{Methodology}

To facilitate the characterisation of the Quaternary geology of the Round 3 area it was initially divided into three Tranches (Figure 1b). A regional geophysical survey was conducted in 2010, acquiring sub-bottom profiles (Sparker and Pinger), magnetometer, sidescan sonar and multibeam datasets with a grid spacing of $2.5 \mathrm{~km}$. In addition, boreholes and Cone Penetration Tests (CPT's) were acquired to fulfil a "background" investigation of the Dogger Bank sedimentary sequence. The same methods where then used to obtain high-resolution datasets over Tranche A (2010), Tranche B (2011/2012) and Tranche C (2013) (Table 2; also see Figure 1b), with sub-bottom profiles run at 100 $\mathrm{m}$ inline and 500 to $1000 \mathrm{~m}$ crossline spacing, and 100\% coverage of multibeam bathymetry and sidescan sonar. In conjunction with the geophysical, geological and geotechnical surveys, a full suite of environmental assessments were also conduced, with results from the ground-truthing and imagery datasets also feeding into the final interpretation.

Once acquired, analysis of the sub-bottom profiles led to the identification of several, laterally extensive, reflections which could be traced across all three Tranches, and a number of laterally discontinuous ones that although not present everywhere, proved important in understanding the evolution of the Dogger Bank (Figure 2). These key reflections were then gridded, and the resultant "horizon maps" interpreted in terms of sedimentary landsystems. In addition, detailed work was undertaken in selected areas to gain a greater understanding of glacitectonic 
deformation, formation of desiccation and ravinement surfaces, and the lateral variability in sedimentary depositional style.

A full suite of geotechnical tests were undertaken by FUGRO, supplemented by the Norwegian Geotechnical Institute (NGI), on spot samples acquired from the boreholes. In addition stratigraphic and geotechnical assessments were undertaken on the clay units within the boreholes in an attempt to identify any systematic variation in their distribution and physical properties and relate these patterns to the seismic data. The resultant correlation between these datasets has been used to extrapolate localised borehole information across the DBZ. This approach, specifically targeted at the Dogger Bank Formation, was adopted to address the issue of significant variation in the physical properties, observed in borehole and CPTU responses, within apparently lithologically identical clay units so improving our understanding of geotechnical responses to key palaeoenvironmental events.

Radiocarbon dating, pollen analysis, macro- (fresh water molluscs, insects, charcoal) and microfaunal (diatoms, foraminifera) identification undertaken by Wessex Archaeology further contributed to the development of a new stratigraphic framework and palaeoenvironmental model.

\section{Revised stratigraphic framework for the Dogger Bank}

The revised stratigraphic framework for the Dogger Bank is divided into six main units, namely; (i) Eem Formation and earlier sediments (oldest), (ii) Dogger Bank Formation, comprising at least two distinct sub-units being the Older and Younger Dogger Bank, (iii) Bolders Bank Formation, (iv) Volans Member; (v) Botney Cut Formation and (vi) Holocene (youngest sediments) (Table 3). The lithological characteristics, distribution and relationships between these stratigraphical units are described below primarily utilizing data from Tranches A and B.

\subsection{Eem and earlier sediments}

The Pleistocene formations present beneath Dogger Bank Formation comprise a variety of sediments deposited in a range of settings including marine, terrestrial, periglacial and intertidal environments. A number of bore holes in the DBZ (e.g. ABH1101 @ 41 m; ABH1134 @ 36.8 m; BH1224@ 43.4 m and BH1282 @ 36.3 m below sea floor (bsf)) demonstrate that the Dogger Bank Formation is directly underlain by a sequence of dense to very dense olive grey, poorly sorted, silty to fine-grained sands containing interbeds of hard clay and greyish brown silty fine sand. These sands contain shell fragments and organic matter, and are interpreted as having been deposited in a marine (? near shore) environment. In the absence of age data it is uncertain whether these sediments belong to the Eem Formation (Tables 1 and 3). However, although previous mapping 
221 (Cameron et al., 1992) has shown that the Eem Formation does extend this far north it typically only occurs as localised deposits. Alternatively, the sands could form part of the Mid Pleistocene Egmond Ground Formation which is also a marine sand-dominated sequence. Analysis of the boreholes (e.g. BH1207 @ 44.5 - 46 m) and detailed mapping of seismic reflectors indicates that the Cleaver Bank Formation, a Mid Pleistocene proglacial clay which occurs between the Egmond Ground and Eem formations (Tables 1 and 3), may also locally be present. These relationships suggest that deposits from the last glacial period (i.e. Dogger Bank Formation) may, in some areas, rest conformably on the pre-glacial Eem Formation, whilst in other areas erosion by the advancing Weichselian ice sheets (BIIS and FIS) led to the removal of both the Eem and Cleaver Bank formations resulting in the Dogger Bank Formation locally resting unconformably on the Egmond Ground Formation.

A BAT test (in-situ gas/fluid sampling test) (Rad et al., 1988; Rad and Lunne 1992) within these sands beneath the Dogger Bank Formation suggests that they contain low-salinity porewaters, which is also supported by calculated resistivity from borehole logs, which could be at odds with the interpretation of the Eem and Egmond Ground formations being fully marine deposits. However, the presence of shell fragments with organic matter suggests late stage deposition in shallow marine conditions as sea levels fell across the North Sea Basin during the EemianWeichselian transition. The low salinities may represent this stage of deposition or the subsequent influence of subsurface fluid flow during the extensive period of terrestrial conditions during the Weichselian.

\subsection{Dogger Bank Formation}

The upper part of the DBZ stratigraphy is dominated by the Dogger Bank Formation (Figure 2; Tables 1 and 3). Historical regional mapping of this formation describes it as a tabular deposit with regular internal reflectors and composed of a clay-rich diamicton containing scarce pebbles and a welldeveloped lamination and/or stratification. However, subsequent high-resolution mapping has demonstrated that this formation has a much more complex internal structural architecture with a number of significant high-amplitude internal reflections present. It has confirmed that the predominant lithology is a clay-rich diamicton containing laterally discontinuous sand lenses; the later often coincident with one of the more distinct high-amplitude internal reflections.

The Dogger Bank Formation is here subdivided into three informal units, termed the "Basal", "Older" and "Younger" Dogger Bank, based on the geotechnical responses combined with lateral extent of significant seismic reflections. The Basal Dogger Bank comprises a series of discrete banklike deposits (Figure 2). Although laterally discontinuous across the DBZ, these basal deposits have been identified in a number of areas where they occur immediately above the marine sands of the 
underlying Eem/Egmond Ground formations. A strong top reflection marking the top of the Basal Dogger Bank is interpreted as a possible desiccation (weathering)/subaerial exposure surface (Figure 2). The Older and Younger Dogger Bank in Tranche A are locally separated by a thin layer of laterally discontinuous coarse sediment (sand and gravel), whilst in Tranche $B$, this division is marked by an downwards increasing sand content in the Younger Dogger Bank. All the Dogger Bank sub-units are composed of generally stiff to very stiff clays, with multiple sand-rich layers. However, towards the east and northeast of Tranche B the overall sand content of the Dogger Bank Formation increases and this subdivision becomes less apparent.

The sub-units of the Dogger Bank Formation also contain laterally discontinuous loess deposits, desiccation surfaces and channels (Figure 2). These channels are often associated with abrupt lithological changes over a relatively short distance (e.g. in the Younger Dogger Bank in BH1296 [4.5 m of stiff clay overlying $8.5 \mathrm{~m}$ of sand] and BH1279 [10.8 m of sand with no clay] being < $50 \mathrm{~m}$ apart). Similar abrupt changes (lithological and geotechnical) are observed occurring over short lateral distances due to the presence/absence of Basal Dogger Bank deposits.

In Tranche A, the Older Dogger Bank is up to $19 \mathrm{~m}$ thick, often forming complex ridges (Figure 2). However in the centre of Tranche $B$, this unit is only $\sim 5 \mathrm{~m}$ thick where it contains thin beds of fine gravel with chalk and shell fragments, and some organic matter. East of this the Older Dogger Bank thickens once again where it forms another ridge-like feature. This unit is often described as "structureless" as a result of locally intense glacitectonic deformation. The overlying Younger Dogger Bank ranges from 5 to $20 \mathrm{~m}$ thick, being locally variable due to the influence of the underlying Older Dogger Bank. The Younger Dogger Bank in Tranche A is often acoustically welllayered, with the thicker units apparently draping and infilling topographic lows, forming basin-like fill between the ridges of the Older Dogger Bank (Figure 2). The Younger Dogger Bank is lithologically variable, but is mainly composed of a predominantly stiff to very stiff greenish grey clay, but with increasing occurrences of thin sand laminae containing some organics and detrital micas as compared to the clays of the Older Dogger Bank.

The Older and Younger Dogger Bank both show evidence of locally intense, southerly directed folding and thrusting as a result of thin-skinned glacitectonic deformation at an oscillating ice margin (Figure 2; Cotterill et al., in press). In the west of Tranche A, large-scale easterly-directed thrusts are observed on the seismic profiles propagating upwards from a major, subhorizontal detachment located at a depth of $\sim 200 \mathrm{~m}$ bsf. Two distinct phases of thrusting have been identified in this area, both of which resulted in the stacking (imbrication) of a number of internally coherent 
area, the Younger Dogger Bank is also affected by thrusting with an apparent sense of movement towards the south/southeast. Clay-rich sediments from boreholes in this Tranche (e.g. BH1207 and BH1224) locally contain polished and striated fracture surfaces which may represent small-scale brittle deformation structures associated with these larger scale thrusts.

291

292

293

294

295

296

297

298

299

300

301

302

303

304

305

306

307

308

309

310

311

312

313

314

315

316

317

\subsection{Bolders Bank Formation}

The Bolders Bank Formation (Tables 1 and 3) typically occurs to the west of Dogger Bank where it rests upon the Older Dogger Bank Formation, and interfingers with the Dogger Bank Formation itself suggesting deposition contemporaneously with the Younger Dogger Bank Formation. Numerous BGS boreholes west of the DBZ have penetrated the formation showing that it is composed of a stiff to very stiff reddish to greyish, massive, slightly sandy calcareous clay (diamicton) which locally possess a sandy layering and glacitectonic deformation structures (Cameron et al., 1992). These diamictons also contains pebbles of chalk thought to be derived from the Cretaceous strata of Eastern England, suggesting that the Bolders Bank Formation was laid down by the BIIS. The presence of these clasts within the Bolders Bank Formation clearly distinguishes these diamictons from the clast poor, olivegrey clays of the Dogger Bank Formation. Although originally thought to possibly be a lateral equivalent of the Dogger Bank Formation with both formations sharing the same basal reflector on early seismic sections (Cameron et al., 1992), new data clearly shows that the Bolders Bank Formation occurs stratigraphically above some parts of the Older Dogger Bank Formation.

BGS regional data across the North Sea indicates that the Bolders Bank Formation is generally less than $5 \mathrm{~m}$ thick, diminishing to $<1 \mathrm{~m}$ to the west of Dogger Bank. The present study has demonstrated that although the formation is limited in its lateral extent, being confined primarily to the western edges of the Dogger Bank and isolated "pockets" within Tranche A where it infills topographic hollows within the upper surface of the Dogger Bank Formation, there are places where the Bolders Bank Formation is much thicker (e.g. BH 1001@ $16.8 \mathrm{~m}$ thick). The restricted occurrence of the Bolders Bank Formation to the western side of the DBZ is thought to be a direct result of this formation having been laid down by ice emanating from the BIIS; an interpretation supported by these diamictons containing detritus derived from the Cretaceous rocks of Eastern England. The Bolders Bank Formation has been interpreted as having been deposited in a subglacial to proglacial environment. Consequently, the distribution of the Bolder Bank Formation could potentially be used to delimit the extent of the advance of UK based ice into the Dogger Bank region during at least part of the late Weichselian glaciation. 


\subsection{Volans Member}

The Volans Member (Table 3) is lithologically similar to the Dogger Bank Formation and has previously been included within this formation (Cameron et al., 1992) where it infills a number of large subglacial/proglacial meltwater channels. Detailed mapping of Tranches A and B has revealed that these channels and the associated sediment infill are absent over this part of the DBZ. However a preliminary assessment of the data from Tranche $C$ suggests the Volans Member channels do occur along the northern margin of the Dogger Bank where they are incised into the Dogger Bank Formation. The channels in general begin near seabed and can be traced to a depth of $\sim 200 \mathrm{~m}$ bsf, suggesting a late stage, but extensive, ice-marginal influence. Detailed analysis of the lithology and thickness of the Volans Member, as well as the morphology of the meltwater channels is the subject of ongoing research.

\subsection{Botney Cut Formation}

In Tranche B a topographic low within the Younger Dogger Bank is filled by a sequence of highly over-consolidated (undrained shear strengths of $>100 \mathrm{kPa}$ ), thinly laminated grey clays containing laminae of silt and fine sand, interbedded with layers of well-sorted sands and occasional gravel horizons. In the central and eastern parts of this deposit these sediments appear to be devoid of shells and other organic material. However, further westwards samples of these deposits indicate that they are more organic-rich and contain bioclastic detritus. Data acquired during the present study clearly demonstrates that this sedimentary sequence is seismically distinct from the Dogger Bank Formation. However, in the past, the seismic character of these sediments have mistakenly formed the basis for the historical descriptions of the Dogger Bank Formation (Cameron et al., 1992; Gatliff et al., 1994); the latter having previously been described as a tabular formation, up to $40 \mathrm{~m}$ in thick, with well-ordered internal reflectors indicative of a sequence of water-lain deposits. Rather than forming part of the Dogger Bank Formation, this lacustrine sequence is here correlated with the Botney Cut Formation (Tables 1 and 3). However, it should also be noted that these sediments are lithologically very similar to descriptions of the Hirundo and Sunderland Ground formations, both of which have previously been interpreted as proglacial sequences.

Detailed mapping of the Botney Cut Formation within Tranche B indicates that the proposed lake basin was periodically drained to the east by a major outflow channel. The sediments within this anastomosing channel record several phases of infill, possibly reflecting the expulsion of water during repeated flash flood (high flow) events which were separated by periods of quiescence (low flow). The regular drainage of the basin, combined with the resulting aerial exposure of the lake sediments to a periglacial environment, may begin to explain the significant geotechnical overconsolidation recorded by the Botney Cut Formation in Tranche B. However, an alternative process 
is over-riding and loading by ice. To the west of the basin there are further lacustrine deposits which contain significant organic matter, indicative of a shallow swamp environment.

Elsewhere within the Dogger Bank area the Botney Cut Formation is seen to infill a series of scaphiform valleys up to $100 \mathrm{~m}$ deep and less than $8 \mathrm{~km}$ wide. These channels extend out from the limits of the Bolders Bank Formation and are predominantly located around the western and northwestern limits of Dogger Bank. The fine-grained sediments of the Botney Cut Formation within these channels are up to $20 \mathrm{~m}$ thick (e.g. BH1004, $19.1 \mathrm{~m}$ thick; BH1074, c. $8.2 \mathrm{~m}$ thick), with the formation passively infilling this earlier formed drainage system. The channels have historically been interpreted as having formed as subglacial meltwater channels (tunnel valleys); i.e. comparable to the much larger Swarte Bank Formation valleys formed during the Elsterian glaciation (Cameron et al., 1992). However, with the radial nature now becoming apparent through the high-resolution dataset, it could be that they formed as a proglacial drainage network. The reduced dimensions of the valleys filled by the Botney Cut Formation may reflect a thinner ice sheet during the later Weichselian glaciation.

\subsection{Holocene}

The Dogger Bank, whilst primarily formed of Quaternary sediments, is surrounded by, and often covered with a veneer of Holocene sediments which are locally being reworked by contemporary marine processes (Tables 1 and 3). Whilst there are a few localised depressions in Tranches A and B where these post-glacial sediments can reach $>25 \mathrm{~m}$ in thickness, infilling older glacially eroded depressions and relict channels, there are also large areas where the Holocene drape is either very thin ( $<1 \mathrm{~m}$ thick) or absent, with older glacial deposits exposed at the seabed (Figure 3 ).

The Holocene is dominated by a sequence of dark olive-grey to very dark grey, fine- to medium-grained sands (although in Tranche B they vary from greyish brown to olive brown) containing shells and a few rounded to angular, coarse gravel-sized clasts. The degree of consolidation of these sands increases downwards with an upper layer, a few centimetres thick, comprising loose silty sand overlying a much thicker (> $10 \mathrm{~m}$ thick) sequence of dense to very dense sand. Locally this dense sand rests upon a mica-rich, fine silty sand unit, which in turn overlies a fine to coarse sandy gravel.

The composition of the sandy Holocene sediments suggests that were largely derived from the reworking of the underlying glacial deposits during the marine transgression which accompanied the inundation of the Dogger Bank by the North Sea. The period between the decline of the Weichselian ice sheets and establishment of full marine conditions on Dogger Bank lasted approximately 12,000 years, spanning the transition between the Pleistocene and Holocene. 
Detailed sedimentological analysis undertaken during the present study has demonstrated for the first time that the oldest part of the post-glacial sequence, represented by the Elbow Formation (Table 3), records a transition from a terrestrial fluvial environment, through fluvial/lacustrine, into estuarine and intertidal deposits laid down in a temperate environment. These three subunits crop out in discrete, very localised pockets across the DBZ. Therefore the oldest post-glacial deposits are not marine, but instead provide evidence for the establishment of a terrestrial tundra environment on Dogger Bank during deglaciation at the end of the Weichselian glaciation, with 174 discoveries of peat listed in the Offshore Renewables Protocol for Archaeological Discoveries (ORPAD) 2012 for the Dogger Bank area, some of which were dated as part of the environmental assessment of the windfarm zone. It is not until the Terschellinger Bank Member of the Nieuw Zeeland Gronden Formation (Table 3) and the Indefatigable Grounds and Bligh Bank Sands formations (Table 3) that the Holocene deposits record full marine conditions across the Dogger Bank (Rijsdijk et al., 2005). Ongoing research is mapping out the palaeo-shoreline as it migrated across the Dogger Bank in response to the rise in sea level during the Holocene.

Extensive areas of flint-rich, medium to coarse gravel at, or near the sea bed have been identified during the mapping of discrete areas of Tranche A (Figure 4). These gravel bodies also contain large cobbles and thick laminae of fine gravel. Although locally exposed the seabed, they often take the form of a buried gravel lag up to $4 \mathrm{~m}$ bsf. In the west of Tranche $A$ the areas of gravel show a distinct NNW-SSE trend, changing to more NW-SE towards the east. These coarse sediments are typically associated with areas of exposed diamicton where they are confined within bathymetric lows (hollows) within a prominent erosion surface. The presence of these coarse-grained deposits results in multiple hyperbolae on the pinger data located along the west-southwest slopes of these hollows. The gravels are thought to have formed as a result of winnowing of the fines from the glacial deposits leaving behind the coarser grain size fraction.

\section{Geomorphology - buried glacial, fluvial and lacustrine landsystems and marine ravinement surfaces}

\subsection{Glacial, glacifluvial and fluvial channels}

A number of the mapped seismic horizons in the DBZ show well-defined channels. The deepest and oldest of the channel systems identified cross both Tranches A and B are interpreted as Swarte Bank channels. The size of the channels varies across the DBZ and are typically larger within Tranche B, reaching widths of $\sim 3.5 \mathrm{~km}$ and depths of up to $200 \mathrm{~m}$, narrowing ( $\leq 2 \mathrm{~km}$ wide, $<150 \mathrm{~m}$ deep) 
westwards into Tranche A (Figure 5a). The sedimentary sequence within the channels records a complex, multiphase history of infill. At the base is a coarse diamicton containing lenses of glaciofluvial sand, possibly representing ice-marginal deposits. This is overlain by laminated glaciolacustrine muds passing upwards into shallow-marine clays which often contain a micro-faunal assemblage typical of very shallow water prone to freezing. Deposition of these sediments is thought to have post-dated the formation of the subglacial meltwater channels and records the progressive retreat of the ice sheet margin and subsequent incursion by the sea. The cold water faunal assemblage present within the marine clays, however, suggests that this shallow marine sequence was deposited proximal to the retreating ice margin.

Higher in the stratigraphy of the DBZ, there are numerous channel complexes recording further periods of subglacial erosion as well as the development of fluvial and glacifluvial (outwash) systems. At the base of the Dogger Bank Formation, a number of sinuous fluvial/glacifluvial channels are incised into the marine sands of the underlying Eem/Egmond Ground formations. The thalwegs of these channels suggest a range of flow directions form N-S, S-N and W-E (Figure 5b). Channels are not only restricted to this complex channelized zone, but also occur with the Dogger Bank Formation and at higher stratigraphic levels within the post-glacial Holocene sedimentary sequence. Channels associated with distinct seismic horizons within the Dogger Bank Formation are interpreted as denoting periods of ice sheet retreat and the exposure of the pre-existing sediments to periglacial activity on a tundra-like plain, incised by braided glacial outwash channels. Deep channels also occur on the western margin of Tranche $\mathrm{A}$ and in the northern part of Tranche $\mathrm{C}$ where they are variably infilled by the Volans Member. These channels are thought to represent late-stage ice-marginal activity (see above), possibly formed during the deglaciation of the DBZ and partially infilled by glacially derived outwash.

Subsequent fluvially derived channelling occurs coincident with the Holocene marine transgression, cutting down into the older terrestrial Holocene sands and pre-existing glacial deposits of the Younger Dogger Bank prior to final inundation. Work by RPS Energy and later Wessex Archaeology suggests that these channels form part of a much larger fluvial drainage system mapped from 3D exploration data (Gaffney et al., 2007) to the south of the DBZ, within the wider Doggerland area.

\subsection{Glacitectonic thrust-moraines and ice-marginal basins}

447 Sub-bottom horizon maps generated from the seismic data for key horizons (e.g. top of the Older 448 Dogger Bank subunit) within the Dogger Bank Formation have revealed the presence of a number of 449 large complexes composed of several arcuate ridge-like features (maximum $3 \mathrm{~km}$ wide, $100 \mathrm{~km}$ 
across and $40 \mathrm{~m}$ high) separated by topographically lower "troughs" (average width of 1 to $5 \mathrm{~km}$ )

451 (Figures $5 c$ and 6 ). These sub-bottom horizon maps are interpreted as palaeo-landform maps and as such have led to the identification of a number of large-scale (up to $30 \mathrm{~km}$ wide), moraine complexes (Figure 6) buried beneath the Younger Dogger Bank and Holocene sedimentary sequences.

In Tranche A, these roughly E-W-trending, arcuate moraine complexes are largely composed of Older Dogger Bank sediments and can be traced laterally across the whole area (a distance of $c$. $90 \mathrm{~km}$ ), and are separated by a number of lower lying basin-like features (up to c. $30 \mathrm{~km}$ across) which are underlain by a much thinner ( $\leq 10 \mathrm{~m}$ thick) Older Dogger Bank sequence. In this area the geometry of the moraines is consistent with an ice movement direction from the N/NW. However, in the western part of Tranche B the Older Dogger Bank forms a series of roughly NE-SW-trending morainic ridges (Figures $5 c$ and 6 ) recording an apparent ice advance from the west. In general, in Tranche B the Older Dogger Bank is much thinner and lithologically more variable than in Tranche A, with the topographically lower central area of Tranche B possibly representing a glacial outwash plain (sandur). However, in the easternmost section of Tranche $B$ there is a significant thickening of the Older Dogger Bank, suggesting that either ice from the west (BIIS) at one point extended across this far forming a terminal moraine set orientated roughly NE-SW, or that ice from the north (FIS) advanced across the area forming a roughly E-W arcuate moraine of which only a portion lies within the imaged DBZ.

Detailed analysis of the seismic data has demonstrated that the moraine complexes coincide with areas of intense deformation and are primarily composed of SE-directed thrusted and folded Older Dogger Bank sediments. Consequently these landforms are interpreted as thrust-moraine complexes and were formed as a result of the thin-skinned glacitectonic deformation of the Older Dogger Bank (Cotterill et al., in press). The Younger Dogger Bank is also subject to a degree of deformation, with some upward penetration of folding and thrusting from the underlying Older Dogger Bank. However, elsewhere these younger sediments are undisturbed with laterally continuous internal reflectors preserving the primary bedded nature of the Younger Dogger Bank. The Younger Dogger Bank can be seen to be infilling the lower areas between the topographically higher thrust-moraines, draping the underlying glaciated surface. The low-lying areas between the moraines therefore represent ice-marginal sedimentary basins which are being progressively filled by outwash laid down in front of the retreating ice margin (Cotterill et al., in press). The complex nature of the thrust-moraines which comprise several intersecting/cross cutting ridges (Figure 6) indicates that they represent periods of stillstand during the overall northward, active retreat of the Weichselian ice sheet from Dogger Bank. 

a number of small (10's meters across), localised depressions, within both the Older and Younger Dogger Bank sediments. It is possible that these depressions may represent extensions of the channel systems identified within the Dogger Bank Formation (see above). However, many of these depressions cannot be tracked between the closely spaced seismic lines (100 m apart) suggesting that they are discrete (isolated) features. It is clearly apparent that the Dogger Bank formed in a highly dynamic glacial to periglacial environment. Consequently, these depressions may have either formed as a result of the growth of ice in the permafrost (Humlum et al., 2003), that on melting left hollows (pingos) that were later infilled with more laminated lacustrine sediments, the formation of Ice wedges, or kettle holes formed above blocks of decaying ice buried beneath glacial outwash and/or stacked within the thrust-moraines.

\subsection{Lacustrine environments}

495 The Botney Cut Formation in Tranche B is interpreted as representing the sedimentary fill to a lake basin (see above) which formed shortly after or during the retreat of the Weichselian ice sheet. At its thickest, the laminated fill reaches up to $35 \mathrm{~m}$, however the majority of the lacustrine deposits are between 15 to $25 \mathrm{~m}$ thick (Figure 7). The lake occupied a topographic low within the upper surface of the underlying Dogger Bank Formation and was bound to the east and south by higher ground formed by the ice-marginal thrust moraines. An outlet channel incised into the eastern side of this morainic dam provided an outlet for periodic drainage of the lake. To the west the lacustrine sediments thin gradually over a distance of $\sim 25 \mathrm{~km}$, with boreholes recovering evidence of peat, wood and tundra bog/scrub soils which contained pollen including Betula nana and Salix aurita (Wessex Archaeology, pers. comm.). Prior analysis of a historical vibrocore suggests a cold water environmental setting (Rex Harland, pers. comm).

The geotechnical results show significant over-consolidation of the laminated unit suggesting loading of the glacially derived soils following the main period of deposition, along with

508 localised north-south orientated deformation in the Younger Dogger Bank unit to the north of the 509 lacustrine deposit, both indicating the presence of ice at some point following or coincident with 510 deposition of the lacustrine unit. It is believed that there was a late stage re-advance from the north 511 that affected Tranche B, resulting in the erosion of two lozenge shaped features that incise down into the lacustrine unit at 900 orientation to the drainage channel that runs out of the lake. These features were later infilled by sands (Figure 3 ) forming locally thick deposits. 
515 As sea levels rose and the North Sea Basin slowly flooded, many authors have proposed that Dogger 516 Bank became an isolated island at between 11 and 8,000 years BP, before finally becoming fully 517 submerged by 5,000 years BP (Shennan et al., 2000; Fitch et al., 2005; Shennan et al., 2008; 518 Hubbard et al., 2009). This would appear to tie in with dating undertaken by Wessex Archaeology on 519 samples from Tranche A, notably from the side of a channel feature (BH1026) where a peat sample 520 returned a date of $9440 \pm 30 \mathrm{BP}(10750-10580 \mathrm{BP} ; 8800-8630 \mathrm{BC})$, and where two channels intersect 521 (ABH1124A) where three dates ranged from $6190 \pm 30 \mathrm{BP}$ (7240-6980 cal BP; 5290-5040 cal BC) and $5227745 \pm 30$ BP $(8600-8440$ cal BP; $6650-6490 \mathrm{cal} \mathrm{BC})$. It must be noted that the dates from the two 523 intersecting channels were reversed with the oldest occurring at the top.

However, sea level rise records from around the world suggest that this transition did not occur smoothly, with pulses of rapid sea level rise (e.g. Meltwater pulse 1A c. 14,000 cal BP; Stanford et al., 2006), "8.2 ka event" (Barber et al., 1999), a 160 year period of climatic cooling and the "Storegga slide" - a tsunami event believed to have occurred around the same 8.2 ka period (Weninger et al., 2008), separated by periods of stillstand. This pulsed pattern of sea-level rise is thought to have been accompanied by continued fluctuations in the volume of the remaining ice sheets during this period of overall climate warming. Most notable was the regrowth of permanent ice caps in the upland areas of the UK during the Younger Dryas, when sea ice probably formed in the marine areas of the North Sea Basin accompanied by periglacial conditions over a terrestrial Dogger Bank.

High-resolution mapping of the south-eastern sector of Tranche A has revealed at least three discrete laterally extensive ravinement surfaces suggesting a phased marine inundation. These surfaces are associated with at least three distinct phases of channelling; a deep feature that can be mapped running from northwest to southeast (Figure 3) with a complex delta-style infill (up to $50 \mathrm{~m}$ thick) coming from a range of orientations, a shallower series of dendritic channels, and another series of less braided channels. More regional mapping across Tranche A has revealed numerous Holocene channel systems.

\section{Palaeoenvironmental Interpretation}

543 It is clear from the above description of the newly revised stratigraphy and recently identified buried 544 landscapes that the evolution of the Dogger Bank can be directly linked to a complex interplay between climatic variation, ice sheet dynamics and sea level change (both rise and fall) 
546 accompanying the growth and subsequent demise of the British and Irish (BIIS) and Fennoscandian

547 (FIS) ice sheets. Approximately 110,000 years before present (BP) the Earth entered a cooling period, 548 initiating the start of the Weichselian ice age and the onset of growth of these two ice caps in the 549 high-ground bordering the North Sea Basin. The FIS centred upon northern Norway and Sweden 550 reached its maximum extent during MIS4 ( 71,000 years BP), expanding once again during MIS2 551 ( 24,000 years BP), with six major advances recorded across Denmark (references). The BIIS located 552 in northern Britain also reached its maximum southerly extent during MIS2 sometime during the 553 period between 25 and 21,000 years BP (reference). The growth of these European ice masses, 554 coupled with the penecontemporaneous expansion of the Laurentide Ice Sheet to cover a significant 555 part of the North American continent (Hughes et al., 2013) had the combined effect of causing a 556 global fall in sea level of $\sim 120 \mathrm{~m}$ (references), ignoring the impacts of local isostatic effects. This 557 global sea level change resulted in fully exposing all of the southern, and the majority of the central, 558 North Sea Basin (references).

The early stages of the evolution of what was to become the Dogger Bank coincided with this sea level fall and decrease in global temperatures. An extensive terrestrial tundra plain environment developed upon the marine sands (e.g. Eem or Egmond Ground formations) which were exposed across the proto-Dogger Bank. Permafrost development within these sands and the freezing of the overlying soils would have altered their nature. Wind erosion is likely to have been prevalent on this tundra plain due to the lack of significant groundcover binding the thin soils leading to the localised deposition of wind-blown loess deposits. This erosion would have been driven by katabatic winds coming off the expanding BIIS and FIS ice sheets to the north, east and west of the Dogger Bank area. Channels at the base of the Dogger Bank Formation and incised into the underlying Eem and Egmont Ground formations indicate that the tundra plain was cross-cut by a series of braided river systems originating out of northern Europe and Britain, with glacial outwash from the BIIS and FIS flowing southwards as these ice masses advanced across the North Sea Basin.

Several workers (Sejrup et al., 2009; Bradwell et al., 2008; Graham et al., 2007) have suggested that at some stage during their evolution the BIIS and FIS converged forming a

573 "confluence zone" located to the north of, and between Dogger Bank and Denmark, with maximum extent of this conjoined ice mass being achieved 25,000 years BP (Mix et al., 2001). However, the actual limits of these major ice masses are poorly understood and constrained (Catt, 1991; Sejrup et al., 2009). Furthermore a number of previous researchers (Houmark-Nielsen, 2011; Carr et al., 2006) have argued that the glacial history of the North Sea Basin is far more complex comprising several phases of ice sheet lobe growth and decay; including the Ferder Episode ( 70,000 years BP), the 
579 Cape Shore Episode ( $29-20,000$ years BP) and the Bolders Bank Episode ( 18-16,000 years BP)

580 (Carr et al., 2006). Evidence for these multiple advances is provided by the recently acquired (this study) high-resolution datasets for the DBZ.

As the BIIS and FIS encroached into the area of the Dogger Bank from the north, east and west, meltwater flowing from these ice masses deposited a complex sequence of glacifluvial and glaciolacustrine sediments on a laterally extensive outwash plain. This sandur was crisscrossed by braided channels dispersing sediment transported by the ice from the highland areas surrounding the North Sea Basin, including the Midland Valley of Scotland, NE England and Scandinavia. These outwash sediments are, at least in part, represented by the Basal and Older Dogger Bank, and would have been progressively overridden by ice advancing across the Dogger Bank, reworking these sediments to form a clay-rich diamicton which characterises the lower part of the Dogger Bank Formation. This clay-rich diamicton can be traced across the DBZ indicating that the maximum extent of ice filling the North Sea Basin was much greater than previously thought (Sejrup et al., 2009; Bradwell et al., 2008; Graham et al., 2007), with the maximum ice limit being located further to the south of the Dogger Bank. Subsequently, the ice covering the Dogger Bank retreated from this maximum limit exposing the glaciated surface at the top of the Older Dogger Bank to periglacial activity and erosion by the wind. This tundra-like plain was incised by braided, glacial outwash channels fed by meltwater liberated from the retreating ice masses. Ponding of this meltwater would have led to the deposition of finer grained glaciolacustrine sediments within small proglacial lakes and ponds. Prolonged exposure of the Older Dogger Bank to periglacial weathering/alteration may have resulted in the observed over-consolidation of these sediments and the formation of a desiccation surface at the top of this sequence; the latter denoted on the seismic data by a prominent zone of high-amplitude reflections. This represents one of a number of potential phases of ice sheet retreat within the North Sea Basin which would have accompanied one of the eight interstadials (warm periods) that occurred during the overall Weichselian glaciation (references Boston et al., 2010). Bank area overriding the Basal and Older Dogger Bank. As this ice approached its maximum extent it began to couple with these underlying sediments resulting in large-scale, ice-marginal to proglacial thrusting and folding. This SE-directed, thin-skinned glacitectonic deformation led to the construction of a laterally extensive thrust-moraine complex across the southern part of the DBZ. The geometry of this thrust-moraine complex, coupled with the SE-directed kinematics of the deformation (Cotterill et al., in press) is consistent with an ice advance from the N/NW. The c. $30 \mathrm{~km}$ 
wide, $100 \mathrm{~km}$ across, arcuate glacitectonic landform is internally complex comprising a series of linear ridges locally cut by meltwater channels (Figure 6b). This complexity indicates that the ice mass covering the DBZ remained in roughly the same position for an extended period of time. Rather than being static, however, this oscillating margin repeatedly detached thrust-bound slices of Basal and Older Dogger Bank sediments pushing them into the developing moraine system. As the ice subsequently pulled back across the DBZ from this "stillstand" position, it repeatedly readvanced into the area resulting in the development of a series of arcuate moraines which chart the progressive northwards retreat (active) of the ice. Consequently, over time the repeated addition of glacially derived sediments onto the Dogger Bank appears to have led to formation a physical barrier (topographic) restricting subsequent ice advances across this part of the North Sea Basin, stalling forward movement and leading to the transferring of lateral deformation forces into the pre-existing sedimentary sequence.

Meltwater and sediment released from the ice margin as is actively retreated northwards across the DBZ led to the deposition of the bedded outwash sediments dominating the Younger Dogger Bank. The coarser grained sand and gravels at the base of the Younger Dogger Bank probably represent more ice-proximal sedimentation becoming progressively finer grained upwards reflecting the transition to more distal sedimentation as the ice margin retreated northwards. These sediments progressively infilled the topographically lower areas (basins) formed between the thrust-moraine complexes. Localised deformation of the Younger Dogger Bank by thrusts and folds propagating upwards from the structurally underling parts of the Dogger Bank Formation indicates that the deposition of at least the early part of this outwash sequence accompanied thrust-moraine development, providing a direct link between ice-marginal sedimentation and glacitectonism (c.f. Phillips et al., 2008). As a consequence of this syntectonic ice-marginal sedimentation the sediments at the base of the Younger Dogger Bank should get progressively younger towards the north. Away from the deformed zones, immediately adjacent to the thrust-moraines, the Younger Dogger Bank sandur deposits are undisturbed with seismic reflections highlighting the laterally extensive, bedded nature of these sediments which locally onlap onto the adjacent glacitectonic landforms. Areas of laminated fine-grained sediments within the Younger Dogger Bank record the establishment of lacustrine environments, either as a result of the formation of proglacial lakes at the ice margin and/or the ponding of meltwater between thrust-moraines. The local increase in the organic content in these sediments provides evidence that as the ice retreated, the sandur was becoming vegetated. As the temperature warmed buried ice and/or permafrost within the outwash began to decay leading to collapse of the overlying sediment and the formation kettle holes and/or pingos, respectively. 
As the ice continued to retreated from Dogger Bank it left behind a glaciated landscape of high-ground formed by the thrust-moraine ridges (up to c. $30 \mathrm{~m}$ high) and intervening, topographically lower sedimentary basins partially filled by outwash, the latter pockmarked by kettle holes, pingos and partially filled glacial drainage channels. The laterally extensive moraine systems appear to have increasingly presented a barrier to meltwater drainage across the sandur. Consequently the increasing volume of meltwater being released from the declining ice sheet as it retreated further to the north was becoming dammed to the south and east by these moraines, leading to the formation of a relatively large ( $750 \mathrm{~km}^{2}$ imaged in Tranche B) proglacial lake over part of the DBZ (Figure7). This lake is thought to have existed for some time allowing the build-up of a thick (up to $35 \mathrm{~m}$ thick) sequence of laminated, fine-grained Botney Cut Formation sediments. To the west the lake was shallower and fringed by marshy ground covered in sparse woodland and tundra bog/scrub. Comparable onshore examples of large ice-dammed lakes found on the UK mainland include Glacial Lake Wear and Glacial Lake Humber (Clark et al., 2004). At some point the moraine system damming the eastern side of the lake became breached providing a periodic outlet for rising meltwater levels within the lake. The sediments within this anastomosing outlet channel suggest that drainage of the lake occurred as a result of a series of discrete flash flood events. The periodic nature of the drainage may be used to suggest that when lake water levels were high enough they overtopped a pre-existing meltwater channel cut through the moraine, the latter forming a spillway which drained water from the lake towards the east. This periodic drainage of the lake led to the aerial exposure of the sediments and to repeated phases of periglacial weathering/alteration. Mapping has indicated three distinct phases of lake infill. The lower lake deposit appears to have been laid down contemporaneously with the Lower Dogger Bank deposits of Tranche A, infilling as the surrounding moraine features in Tranche B developed.

The Dogger Bank then entered a period of significant climatic and environmental flux following the Last Glacial Maximum, and regional decay of the large self-sustaining northern hemisphere ice sheets. Evidence of changing pollens and increased organic content, evident from analysis of core material recovered from Dogger Bank, combined with multiple phases of channelling and the formation of more than one ravinement surface, suggest a dynamic environment encompassed the transition between the LGM and full marine inundation. As sea levels rose, meandering fluvial systems initially cut down through the Dogger Bank, followed by complete marine inundation sometime between 6000-10000 BP (Shennan et al., 2000; Fitch et al., 2005). However dates acquired from Tranche A indicate a late inundation around xxx. The nature of this transition from tundra plain to fully marine conditions would have encompassed a number of different depositional environments in a relatively short time period - from terrestrial tundra with 
fluvial, windblown and lacustrine deposits as well as sub-glacial and pro-glacial sediments, through tidal embayment, estuarine and brackish deposits to fully marine. Dogger Bank therefore represents a topographic feature that has been subjected to numerous influences and environments, increasing the complexity associated with sedimentary processes and the potential for changes to geotechnical properties of the soils.

\section{Conclusions}

The results of a detailed multidisciplinary clearly demonstrate that the Dogger Bank in the southern central North Sea is an internally complex topographic feature which evolved as a result of the complex interplay between climatic variations, ice sheet dynamics and sea level change accompanying the growth and subsequent demise of the British and Irish and Fennoscandian ice sheets during the Weichselian glaciation.

The early stages of its evolution were terrestrial and coincided with the onset of this glaciation. As sea levels fell, an extensive terrestrial tundra plain environment developed across the emerging Dogger Bank, dissected by a series of braided river systems originating out of northern Europe and Britain. Meltwater flowing from the advancing ice sheets led to further incision and deposition of a complex sequence of glacifluvial and glaciolacustrine sediments on a laterally extensive outwash plain. These sediments were subsequently overridden by the advancing ice and reworked to form an extensive sheet of clay-rich diamicton found across the entire Dogger Bank, indicating that the maximum ice limit lay further to the south. Subsequent retreat of the ice sheet exposed this glaciated surface to periglacial activity and wind erosion, as well as further incision by braided, glacial outwash channels fed by meltwater liberated from the melting ice and the local formation of small proglacial lakes and ponds. This represents one of a number of potential phases of ice sheet retreat from the North Sea Basin, possibly coinciding with one of the eight interstadials (warm periods) which occurred during the Weichselian glaciation.

During a later stage of this glaciation, ice advancing from the north into the Dogger Bank area resulted in large-scale SE-directed thrusting and folding of the pre-existing sediments, and the construction of a large (c.30 km wide, $100 \mathrm{~km}$ across), arcuate moraine system marking its maximum extent. As the ice sheet eventually pulled back from this "stillstand" position it repeatedly readvanced into the area leading to the deposition of a complex sequence of outwash sediments and development of a series of recessional moraines charting its active retreat northwards. Consequently, over time the repeated addition of glacially derived sediments onto the Dogger Bank 
coupled with large-scale glacitectonism led to formation a physical barrier (topographic) restricting subsequent ice advances across this part of the North Sea Basin. The laterally extensive moraine systems increasingly presented a barrier to drainage across the sandur, leading to the damming of the meltwater liberated from the declining ice sheet, and the formation of a relatively large ( 750 $\mathrm{km}^{2}$ ) proglacial lake fringed to the west by vegetated marshy ground. This lake periodically drained to the east via a pre-existing meltwater channel cut through the moraine.

Following the decay of the ice sheets surrounding the North Sea Basin, the Dogger Bank entered a period of significant climatic and environmental flux as the area was initially incised by meandering fluvial systems, prior to complete marine inundation as sea levels rose during the Holocene.

\section{Acknowledgements}

The authors would like to thank the Forewind Consortium (Statoil, Statkraft, RWE and SSE) for their permission to use the datasets acquired during surveys conducted for licensing purposes. In addition we thank colleagues at BGS, NGI, RPS and the University of Sterling including Tom Bradwell, Tom Lunne, Don de Groot, Oyvind Blaker, David Long, Astrid Ruiter, Callum Duffy, Andrew Finlayson and Gareth Carter for their help and input into the discussion process. CJC, ERP and DD publish with permission of the Executive Director of the British Geological Survey, Natural Environment Research Council.

\section{References}

Balson, P.S., Cameron, T.D.G. 1985. Quaternary mapping offshore East Anglia. Marine Geology 9, pp. 221-239

Barber, D.C., Dyke, A., Hillaire-Marcel, C., Jennings, A.E., Andrews, J.T., Kerwin, M.W., Bilodeau, G., McNeely, R., Southon, J., Morehead, M.D., Gagnon, J. M. 1999. Forcing of the cold event 8,200 years ago by catastrophic drainage of Laurentide Lakes. Nature 400 (6742): 344-8. doi:10.1038/22504.

Boston, C.M., Evans, D.J.A., Ó Cofaigh, C. 2010. Styles of till deposition at the margin of the Last Glacial Maximum North Sea lobe of the British-Irish Ice Sheet: an assessment based on geochemical properties of glacigenic deposits in eastern England. Quaternary Science Reviews 29, 3184-3211. 
Bradwell, T., Stoker, M.S., Golledge, N.R., Wilson, C.K., Merritt, J.W., Long, D., and others. 2008. The northern sector of the last British Ice Sheet: maximum extent and demise. Earth Science Reviews 88, 207-226.

British Geological Survey and Rijks Geologische Dienst. 1989. Silver Well Quaternary Geology. 1:250 000. Keyworth, Nottingham: British Geological Survey.

British Geological Survey and Rijks Geologische Dienst. 1991. Dogger Quaternary Geology. 1:250 000. Keyworth, Nottingham: British Geological Survey.

Cameron, T.D.J., Stoker, M.S., Long, D. 1987. The history of Quaternary sedimentation in the UK sector of the North Sea Basin. Journal of the Geological Society, London 144, 43-58.

Cameron, T.D.J., Crosby, A., Balson, P.S., Jeffery, D.H., Lott, G.K., Bulat, J., Harrison, D.J. 1992. United Kingdom offshore regional report: the geology of the southern North Sea. London: HMSO for the British Geological Survey.

Carr, S.J., Holmes, R., van der Meer, J.J.M., Rose, J. 2006. The Last Glacial Maximum in the North Sea Basin: micromorphological evidence of extensive glaciation. Journal of Quaternary Science 21, 131153.

Caston, V.N.D. 1977. A new isopachyte map of the Quaternary of the North Sea. Institute of Geological Sciences Report 10 (11), 3-10.

Caston, V.N.D. 1979. The Quaternary sediments of the North Sea. In: Banner, F.T., Collins, M.B., Massie, K.S. (eds) The North-West European shelf seas: The sea bed and the sea in motion. 1. Geology and Sedimentology. Elsevier, New York. 195-270.

Catt, J.A. 1991. Late Devensian glacial deposits and glaciations in eastern England and the adjoining offshore region. In: Ehlers J, Gibbard PL, Rose J (eds) Glacial Deposits in Great Britain Ireland. A.A. Balkema: Rotterdam. 61-68.

Clark, C.D., Evans, D.J.A., Khatwa, A., Bradwell, T., Jordan, C.J., Marsh, S.H., Mitchell, W.A., Bateman, M.D. 2004. Map and GIS database of glacial landforms and features related to the last British Ice Sheet. Boreas 33, 359-375.

Cotterill, C., Phillips, E., James, L., Forsberg, C.F. Tjelta, T.I. in press. How understanding past landscapes can inform present day site investigations: A case study from Dogger Bank, southern central North Sea. NSG Marine Special Publication. 
Diesing, M., Ware, S., Foster-Smith, R., Stewart, H., Long, D., Vanstaen, K., Forster, R., Morando, A. 2009. Understanding the marine environment - seabed habitat investigations of the Dogger Bank offshore draft SAC. Joint Nature Conservation Committee, Peterborough. JNCC Report No. 429, 89 pp., 5 Appendices.

Eisma, D., Jansen, J.H.F., van Weering, T.C.E. 1979. Sea floor morphology and recent sediment movement in the North Sea. In: Oele, E., Schuttenhelm, R.T.E., Wiggers, A.J. (eds) The Quaternary history of the North Sea. Acta Univ. Ups. Symposium. Univ. Ups Annum Quintegentesimum Celebrantis, Uppsala. 217-231.

Ehlers, J., 1990. Reconstructing the dynamics of the north-west European Pleistocene ice sheets. Quaternary Science Reviews 9, 71-83.

Fitch, S., Thomson, K., Gaffney, V. 2005 Late Pleistocene and Holocene depositional systems and the palaeogeography of the Dogger Bank, North Sea. Quaternary Research 64, 185-196

Gaffney, V., Thomson, K., Fitch, S. 2007. Mapping Doggerland, the Mesolithic landscapes of the southern North Sea. Archaeopress, 131 pp.

Gatliff, R.W., Richards, P.C., Smith, K., Graham, C.C., McCormack, M., Smith, N.J.P., Jeffery, D., Long, D., Cameron, T.D.J., Evans, D., Stevenson, A.G., Bulat, J., Ritchie, J.D. 1994. United Kingdom offshore regional report: the geology of the central North Sea. London: HMSO for the British Geological Survey.

Glennie, K.W., Underhill, J.R., 1998. Origin, development and evolution of structural styles. In: Glennie, K.W. (ed.) Petroleum Geology of the North Sea: Basic Concepts and Recent Advances (fourth edition). Blackwell Science Ltd., Oxford, 42-84.

Graham, A.G.C., Lonergan, L., Stoker, M.S. 2007. Evidence for Late Pleistocene ice stream activity in the Witch Ground Basin, central North Sea, from 3D seismic reflection data. Quaternary Science Reviews 26, 627-643.

Graham, A.G.C., Stoker, M.S., Lonergan, L., Bradwell, T., Stewart, M.A., 2011. The Pleistocene glaciations of the North Sea Basin. In: Ehlers, J., Gibbard, P.L. (eds) Quaternary Glaciations - Extent and Chronology ( $2^{\text {nd }}$ Edition), 261-278.

Houmark-Nielsen, M., 2011. Pleistocene glaciations in Denmark: a closer look at chronology, ice dynamics and landforms. Developments in Quaternary Science 15, 47-58. 
Hubbard, A.L., Bradwell, T., Golledge, N.R., Hall, A., Patton, H., Sugden, D., Cooper, Stoker, M.S. 2009. Dynamic cycles, ice streams and their impact on the extent, chronology and deglaciation of the British-Irish ice sheet. Quaternary Science Reviews 28, 758-776.

Hughes, P.D., Gibbard, P.L., Ehlers, J. 2013. Timing of glaciations during the last glacial cycle; Evaluating the concept of a global "Last Glacial Maximum" (LGM). Earth Science Reviews, doi: 10.1016/j.earscirev.2013.07.003

Humlum, O., Instanes, A., and Sollid, J.L. 2003. Permafrost in Svalbard: a review of research history, climatic background and engineering challenges. Polar Research 22, 191-215.

Huuse, M., Lykke-Andersen, H., Michelsen, O. 2001. Cenozoic evolution of the eastern Danish North Sea. Marine Geology 177, 232-269.

Jansen, J.H.F., van Weering, T.C.E., Eisma, D. 1979. Late Quaternary Sedimentation in the North Sea. In: Oele, E., Schuttenhelm, R.T.E., Wiggers, A.J. (eds) The Quaternary history of the North Sea. Acta Univ. Ups. Symposium. Univ. Ups Annum Quintegentesimum Celebrantis, Uppsala 2. 175-187

Kristensen, T.B., Huuse, M., Piotrowski, J.A., Clausen, O.R. 2007. A morphometric analysis of tunnel valleys in the eastern North Sea based on 3D seismic data. Journal of Quaternary Science 22, 801815.

Kuhlmann, G., Wong, T.E. 2008. Pliocene palaeoenvironment evolution as interpreted from 3Dseismic data in the southern North Sea, Dutch offshore sector. Marine and Petroleum Geology, 25, pp 173-189

Lonergan, L., Maidment, S.C.R., Collier, J.S. 2006. Pleistocene subglacial tunnel valleys in the central North Sea basin: 3-D morphology and evolution. Journal of Quaternary Science 21, 891-903.

Mix A, Bard E, Schneider, R. 2001. Environmental processes of the Ice Age: land, oceans, glaciers (EPILOG). Quaternary Science Reviews 20, 627-657.

Ottesen, D., Dowdeswell, J.A., Bugge, T. 2014. Morphology, sedimentary infill and depositional environments of the Early Quaternary North Sea Basin $\left(56^{\circ}\right.$ to $\left.62^{\circ} \mathrm{N}\right)$. Marine and Petroleum Geology doi: 10.1016/j.marpetgeo.2014.04.007.

Phillips, E., Lee, J.R., Burke, H. 2008. Progressive proglacial to subglacial deformation and syntectonic sedimentation at the margins of the Mid-Pleistocene British Ice Sheet: evidence from north Norfolk, UK. Quaternary Science Reviews 27, 1848-1871. 

resolution from low frequencies. Journal of Applied Geophysics 53, 273-298.

830

Rad, N.S. Sollie, S. Lunne, T., Torstensson, B.A. 1988. A new offshore soil investigation tool for measuring the in situ coefficient of permeability and sampling pore water and gas. International

832 Conference on the Behaviour of Offshore Structures, 5. BOSS'88. Trondheim 1988. Proceedings, Vol. $8331,409-417$.

834 Rad, N.S., Lunne, T. 1992. BAT-probe: for avoidance of hazards of shallow gas pockets. Sea 835 Technology, February, 37-39.

Rijsdijk, K.F., Passchier, S., Weerts, H.J.T., Laban, C., van Leeuwen, R.J.W., Ebbing, J.H.J. 2005. Revised Upper Cenozoic stratigraphy of the Dutch sector of the North Sea Basin: towards an integrated lithostratigraphic, seismostratigraphic and allostratigraphic approach. Netherlands Journal of Geosciences (Geologie en Mijnbouw) 84, 129-146.

Sejrup, H.P., Aarseth, I., Ellingsen, K.L., Reither, E., Jansen, E., Løvlie, R., Bent, A., Brigham-Grette, J., Larsen, E., Stoker, M. 1987. Quaternary stratigraphy of the Fladen area, central North Sea: a multidisciplinary study. Journal of Quaternary Science 2, 35-58.

Sejrup, H.P., Aarseth, I., Haflidason, H., Løvlie, R., Bratten, Å., Tjøstheim, G., Forsberg, C.F., Ellingsen, K.L. 1995. Quaternary of the Norwegian Channel: glaciation history and palaeoceanography. Norwegian Journal of Geology 75, 65-87.

Sejrup, H.P., Larsen, E., Landvik, J., King, E.L., Haflidason, H., Nesje, A., 2000. Quaternary glaciations in southern Fennoscandia: evidence from southwestern Norway and the northern North Sea region, Quaternary Science Reviews 19, 667-685.

849 Sejrup, H.P., Larsen, E., Haflidason, H., Berstad, I.M., Hjelstuen, B.O., Jonsdottir, H., King, E.L., 850 Landvik, J.Y., Longva., O., Nygård, A., Ottesen, D., Raunholm, S., Rise, L., Stalsberg, K. 2003. Configuration, history and impact of the Norwegian Channel Ice Stream. Boreas 32, 18-36. glaciation history of south-western Norway, North Sea and eastern UK. Quaternary Science Reviews $28,370-380$. 
Holocene. In: Shennan, I., Andrews, J. (eds) Holocene Land-Ocean Interaction and Environmental Change around the North Sea. Geological Society, London, Special Publications, 166, 299-319.

Shennan, I., Bradley, S., Milne, G., Brooks, A., Bassett, S., Hamilton, S. 2006: Relative sea-level changes, glacial isostatic modelling and ice-sheet reconstructions from the British Isles since the Last Glacial Maximum. Journal of Quaternary Science 21, 585-599.

Stanford, J.D., Rohling, E.J., Hunter, S.E., Roberts, A.P., Rasmussen, S.O., Bard, E., McManus, J., Fairbanks, R.G. 2006. Timing of meltwater pulse 1a and climate responses to meltwater injections. Palaeoceanography 21, PA4103, doi:10.1029/2006PA001340.

Stewart, M.A., Lonergan, L., Hampson, G.J., 2013. 3D seismic analysis of buried tunnel valleys in the central North Sea: morphology, cross-cutting generations and glacial history. Quaternary Science Reviews 72, 1-17.

Stewart, M.A., Lonergan, L., 2011. Seven glacial cycles in the middle-late Pleistocene of northwest Europe; geomorphic evidence from buried tunnel valleys. Geology 39, 283-286.

Stoker, M.S., Balson, P.S., Long, D., Tappin, D.R. 2011. An overview of the lithostratigraphical framework for the Quaternary deposits on the United Kingdom continental shelf. British Geological Survey Research Report RR/11/03. 48 pp.

Weninger, B., Schulting, R., Bradtmöller, M., Clare, L., Collard, M., Edinborough, K., Hilpert, J., Jöris, O., Niekus, M., Rohling, E.J., Wagner, B. 2008. The catastrophic final flooding of Doggerland by the Storegga Slide tsunami. Documenta Praehistorica 35, 1-24.

Wingfield, R. 1990. The origin of major incisions within the Pleistocene deposits of the North Sea. Marine Geology 91, 31-52.

Zagwijn, W.H. 1989. The Netherlands during the Tertiary and the Quaternary: A case history of Coastal Lowland evolution. Geologie en Mijnbouw 68, 107-120.

Zagwijn, W.H., Doppert, J.W.C. 1978. Upper Cainozoic of the Southern North Sea basin: Palaeoclimate and Palaeogeographic evolution. Geologie en Mijnbouw 57, 588-588.

Zanella, E., Coward, M.P. 2003. Structural framework. In: Evans, D., Graham, C., Atmour, A., Bathurst, P. (eds) The Millennium Atlas: Petroleum Geology of the Central and Northern North Sea. The Geological Society of London, London. 45-59. 
887 Figure 1. (a) Map showing the location of the Dogger Bank in the southern North Sea Basin, and the Round 3 windfarm zone indicated by the red polygon. The limit of the UK territorial waters is also marked in red. DigBath bathymetry (UK waters) and GEBCO bathymetry (Non UK waters).; and (b) Map showing the location of the Dogger Bank windfarm zone (DBZ) and Tranches A, B and C, as well as the extent of the regional and high-resolution seismic surveys acquired during the site survey.

892

Figure 2. The subsurface seismic profile and geological cross-section constructed for a NE-SW orientated line located in the southern part of Tranche A.

Figure 3. Map of sand thickness within for Tranches A and B of the Dogger Bank windfarm zone one (depth in metres below seabed) (Courtesy of RPS Energy Ltd.).

Figure 4. Sidescan sonar data overlain by a map of the gravel lag deposits within part of Tranche A. Orange - potential buried gravel deposits (within $2 \mathrm{~m}$ bsf); yellow - gravel mapped at seabed; red line - margin of Dogger Bank windfarm zone; black lines - potential cable corridor export routes.

Figure 5. Horizon maps generated form detailed mapping of key subsurface reflectors identified on the high-resolution seismic survey profiles: (a) map showing the distribution of Swarte Bank channels; (b) map of the base of the Dogger Bank Formation showing a network of braided channels incised into the underlying Eem Formation marine sands; and (c) map of the upper surface of the Basal Dogger Bank showing the presence of a series of arcuate moraines (All horizons courtesy of RPS Energy Ltd).

Figure 6. (a) Horizon map constructed for the top of the Older Dogger Bank; and (b) Landform map of the buried glacial landscape concealed within the Dogger Bank Formation comprising a suite of topographically higher arcuate moraine ridges separated by lower lying basinal areas and meltwater channels (after Cotterill et al., in press).

Figure 7. Horizon map showing the base of the lacustrine unit identified within Tranche B (Courtesy of RPS Energy Ltd.).

\section{Tables}

913 Table 1. Lithostratigraphic subdivisions of the late Tertiary and Quaternary sedimentary sequences 914 identified within the North Sea basin (Stoker et al., 2011). 
915 Table 2. Geophysical and geotechnical datasets acquired between 2010 and 2013 (Data courtesy of 916 Forewind).

917 Table 3. Subdivisions of the lithostratigraphy within the Quaternary periods showing the multiple 918 divisions within the Dogger Bank Formation (after Stoker et al., 2011).

919

920 


\begin{tabular}{|c|c|c|c|c|c|c|}
\hline \multicolumn{2}{|c|}{$\begin{array}{c}\text { Seismo-stratigraphic } \\
\text { elements and lithogenic } \\
\text { division }\end{array}$} & $\begin{array}{l}\text { Southern North Sea } \\
\text { Formation }\end{array}$ & Depositional Environment & \multicolumn{2}{|c|}{ Inferred chrono-stratigraphy } & $\begin{array}{l}\sim \text { Chrono-stratigraphic equivalent formations } \\
\text { in the central North Sea (north of 56-N) }\end{array}$ \\
\hline \multirow{17}{*}{ 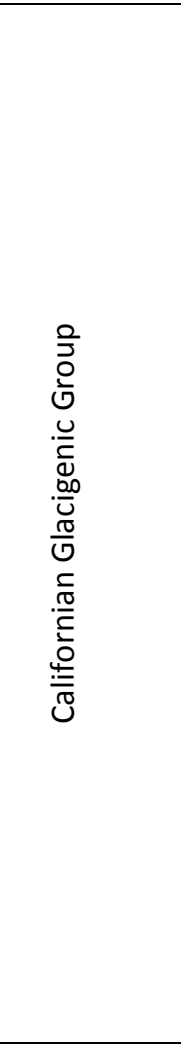 } & $\mathrm{J}$ & Various Formations & Marine & \multicolumn{2}{|c|}{ Holocene } & \multirow{3}{*}{ Witch Ground } \\
\hline & \multirow[t]{2}{*}{$\mathrm{H}$} & Sunderland Ground* (SG) & $\begin{array}{l}\text { Subglacial to Proglacial: } \\
\text { Glaciolacustrine to Glaci marine }\end{array}$ & \multirow{7}{*}{\multicolumn{2}{|c|}{ Upper Weichselian }} & \\
\hline & & Botney cut (BCT) & $\begin{array}{l}\text { Subglacial: Glaciolacustrine to } \\
\text { Glaciomarine }\end{array}$ & & & \\
\hline & \multirow{5}{*}{$\mathrm{G}$} & Kreftenheye $(\mathrm{KR})^{*}$ & Periglacial: Fluvial & & & \multirow[t]{3}{*}{ Swatchway } \\
\hline & & Twente (TN)* & Periglacial: Aeolian & & & \\
\hline & & Well Ground (WLG) & Proglacial: Fluvial & & & \\
\hline & & Dogger Bank (DBK) & $\begin{array}{c}\text { Proglacial: Glaciomarine to } \\
\text { Glaciolacustrine }\end{array}$ & & & \multirow{6}{*}{ Coalpit } \\
\hline & & Bolders Bank (BDK) & Subglacial: Terrestrial & & & \\
\hline & \multirow{3}{*}{$\mathrm{F}$} & Brown Bank (BNB) & Marine to Lacustrine & \multicolumn{2}{|c|}{ Lower Weichselian } & \\
\hline & & 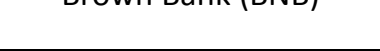 & 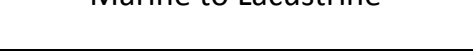 & \multirow{8}{*}{$\begin{array}{l}\text { Middle } \\
\text { Pleistocene }\end{array}$} & Eemian & \\
\hline & & Eem (EE) & Marine & & & \\
\hline & \multirow{3}{*}{$E$} & Tea Kettle Hole (TKH) & Periglacial Aeolian & & Saalian & \\
\hline & & & & & & Fisher \\
\hline & & Cleaver Bank (CLV) & Proglacial Glaciomarine & & Holstenian & \multirow{4}{*}{ Ling Bank } \\
\hline & \multirow[b]{2}{*}{ D } & Egmond Ground (EG) & Marine & & & \\
\hline & & Sand Hole & Marine (lagoonal) & & & \\
\hline & $\mathrm{C}$ & Swarte Bank (SBK) & $\begin{array}{l}\text { Subglacial: Glaciolacustrine to } \\
\text { glaciomarine }\end{array}$ & & Elsterian & \\
\hline $\begin{array}{l}\text { Dunwich } \\
\text { Group }\end{array}$ & $\mathrm{B}$ & Yarmouth Roads (YR) & Non marine fluvial to intertidal & \multicolumn{2}{|c|}{$\begin{array}{l}\text { Lower Pleistocene to Middle } \\
\text { Pleistocene } \\
\end{array}$} & \multirow{8}{*}{ Aberdeen Ground } \\
\hline \multirow{7}{*}{ 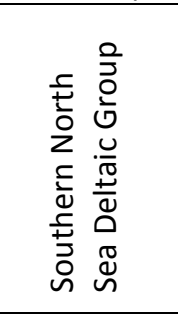 } & \multirow{7}{*}{ A } & Batavia (B) & Marine & \multirow{7}{*}{\multicolumn{2}{|c|}{ Lower Pleistocene }} & \\
\hline & & Aurora (AA) & Marine & & & \\
\hline & & Outer Silver Pit (OSP) & Marine & & & \\
\hline & & Markham's Hole (MKH) & Marine & & & \\
\hline & & Winterton Shoal (WN) & Marine & & & \\
\hline & & ljmuiden Ground (IJ) & Marine & & & \\
\hline & & Smith's Knoll (SK)* & Marine & & & \\
\hline
\end{tabular}




\begin{tabular}{|l|l|l|l|}
\hline Tranche & $\begin{array}{l}\text { Sub-Bottom Profiles } \\
\text { (Line km's) }\end{array}$ & Boreholes & CPTs \\
\hline Regional & 7,000 & 6 & 12 \\
\hline A & 28,000 & 45 & 76 \\
\hline B & 17,000 & 20 & 83 \\
\hline C & 14,000 & & \\
\hline
\end{tabular}




\begin{tabular}{|c|c|c|c|c|c|}
\hline Era & Formation & $\begin{array}{l}\text { Revised } \\
\text { Units }\end{array}$ & Depositional Environment & Description & MIS \\
\hline \multirow{5}{*}{ 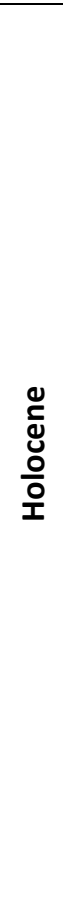 } & Bligh Bank & \multirow{5}{*}{ VI } & $\begin{array}{l}\text { Marine } \\
\text { Derived from re-worked glacial deposits }\end{array}$ & Modern mobile medium to fine grained sands & \multirow{5}{*}{1} \\
\hline & $\begin{array}{l}\text { Indefatigable } \\
\text { Grounds }\end{array}$ & & $\begin{array}{l}\text { Marine } \\
\text { Derived from re-worked glacial deposits }\end{array}$ & $\begin{array}{l}\text { Gravelly sands and sandy gravel forming a veneer of } \\
\text { variable thickness over glacial till. }\end{array}$ & \\
\hline & $\begin{array}{l}\text { Nieuw } \\
\text { Zeeland } \\
\text { Gronden } \\
\text { Terschellinger } \\
\text { Bank Member }\end{array}$ & & $\begin{array}{l}\text { Marine } \\
\text { Proposed to be the first fully marine deposit following the } \\
\text { transition from glacial to interglacial. The base of this unit is } \\
\text { proposed to be the erosional marine ravinement surface. } \\
\text { Extensively found across Dogger Bank although of variable } \\
\text { thickness. }\end{array}$ & $\begin{array}{l}\text { Terschellinger Bank Member } \\
\text { Slightly muddy fine grained sand containing sparse } \\
\text { numbers of marine molluscs. } \\
\text { Re-worked periglacial and glacial deposits }\end{array}$ & \\
\hline & Well Hole & & $\begin{array}{l}\text { Shallow marine } \\
\text { Unconformably overlies the late glacial Botney Cut, infilling } \\
\text { depressions. }\end{array}$ & $\begin{array}{l}\text { Laminated fine grained sands and sandy muds. } \\
\text { Variable thickness and laterally discontinuous }\end{array}$ & \\
\hline & Elbow & & $\begin{array}{l}\text { Early stage marine transgression moving into estuarine to } \\
\text { intertidal } \\
\text { Between the end of the } \mathrm{LGM} \sim 17,000 \text { years BP and final flooding } \\
\text { of Dogger Bank at } \sim 6,000 \text { years } B P \text {, transitional deposits were } \\
\text { laid down encompassing a fluvially incised tundra plain, } \\
\text { estuarine, brackish intertidal to shallow marine }\end{array}$ & $\begin{array}{l}\text { Extensive in the Dutch sector but laterally discontinuous } \\
\text { and patchy across the Dogger Bank zone with limited } \\
\text { expression in Tranche B only. Upper - fine grained muddy } \\
\text { sands and interbedded clays containing a mollusc } \\
\text { assemblage; Middle - brackish marine clay - liable to } \\
\text { represent early stages of sporadic marine inundation; } \\
\text { Lower - basal peats - liable to represent a fluvially incised } \\
\text { environment }\end{array}$ & \\
\hline \multirow{4}{*}{ 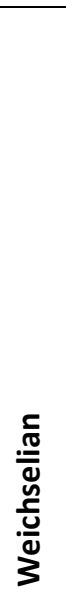 } & Botney Cut & $\boldsymbol{V}$ & $\begin{array}{l}\text { Sub-glacial } \\
\text { Generally described as scaphiform channel infill radiating out } \\
\text { from the edges of the Bolders Bank Formation. However, in } \\
\text { Tranche B the upper unit is found infilling a significant basin } \\
\text { formed in the Dogger Bank Formation. }\end{array}$ & $\begin{array}{l}\text { Upper - stiff to soft glaciolacustrine and glaciomarine } \\
\text { muds with patchy cobbles. Possible evidence of periodic } \\
\text { exposure through flash drainage of the pro-glacial lake } \\
\text { with some horizons more acoustically distinct. }\end{array}$ & \multirow{4}{*}{$\begin{array}{c}2-4 \\
5 a- \\
5 d\end{array}$} \\
\hline & Volans & IV & $\begin{array}{l}\text { Sub-glacial } \\
\text { Found infilling erosional glacial channels associated with the } \\
\text { Weichselian glacial period, lying within the Dogger Bank } \\
\text { Formation, particularly along its northern limits. In 2005, Rijsdijk } \\
\text { et al. (p. 134) proposed integrating Dogger Bank, Bolders Bank, } \\
\text { Volans and Well Ground Fomations into one Formation known as } \\
\text { the Dogger Bight in the Dutch sector of the Dogger Bank. }\end{array}$ & $\begin{array}{l}\text { Lithologically they appear identical to the Dogger Bank } \\
\text { sediments, forming contemporaneously. }\end{array}$ & \\
\hline & Bolders Bank & III & Glacial & Clay with some silty, sandy and gravelly content & \\
\hline & & II & Younger Dogger Bank 1, Glacial & Dense sand and silty clay with silt and clay layers and & \\
\hline
\end{tabular}




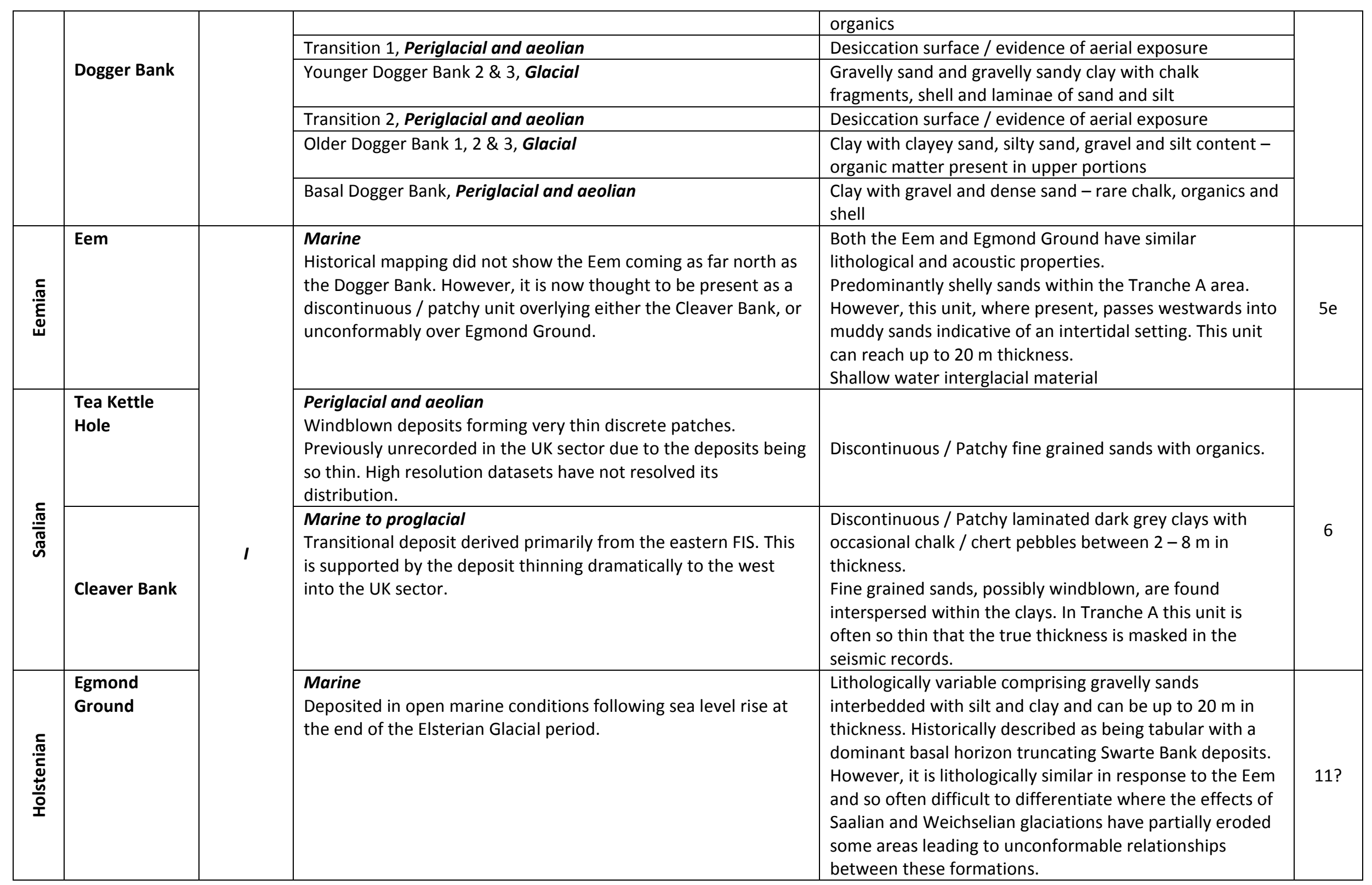




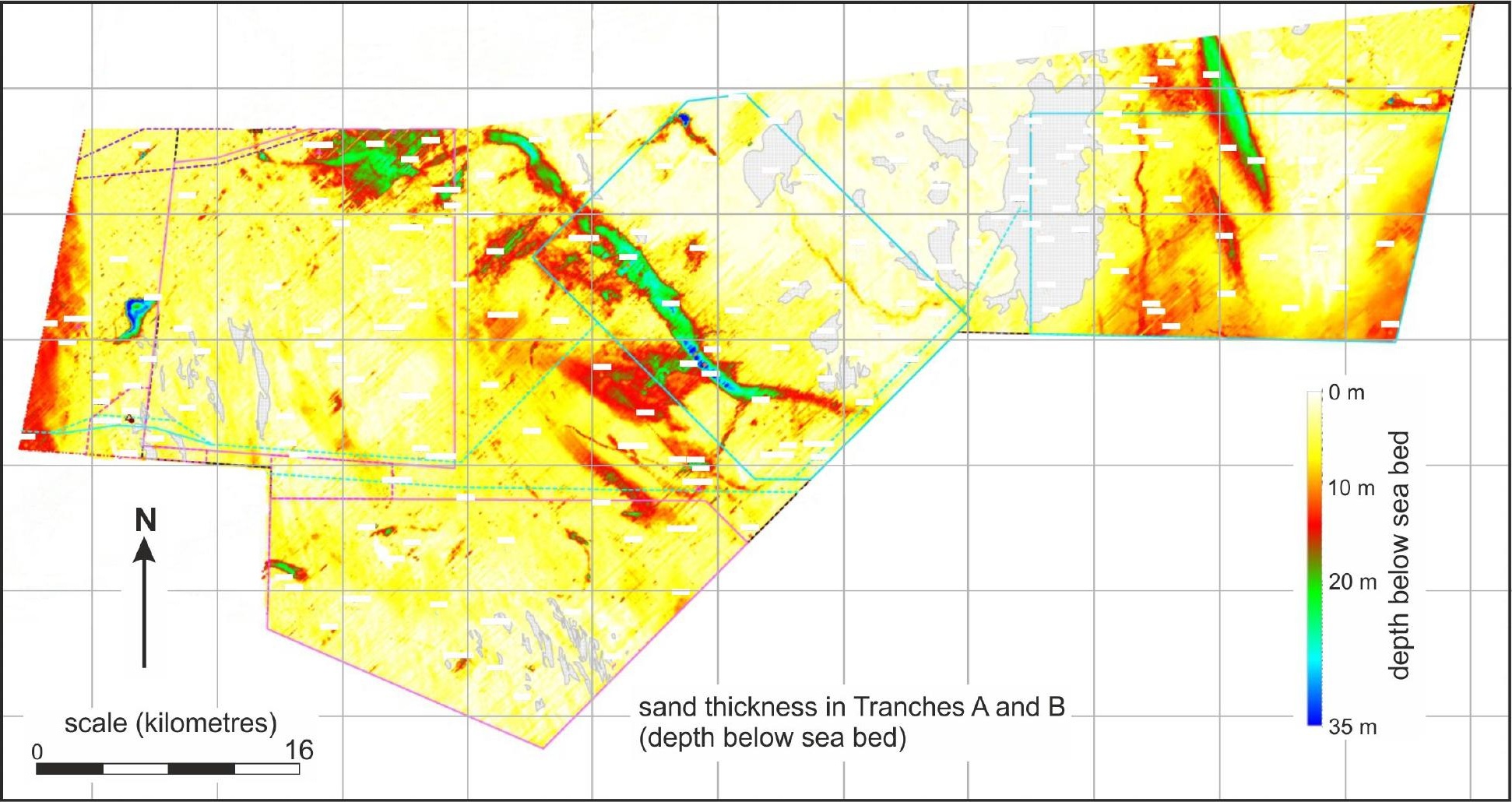


(a)

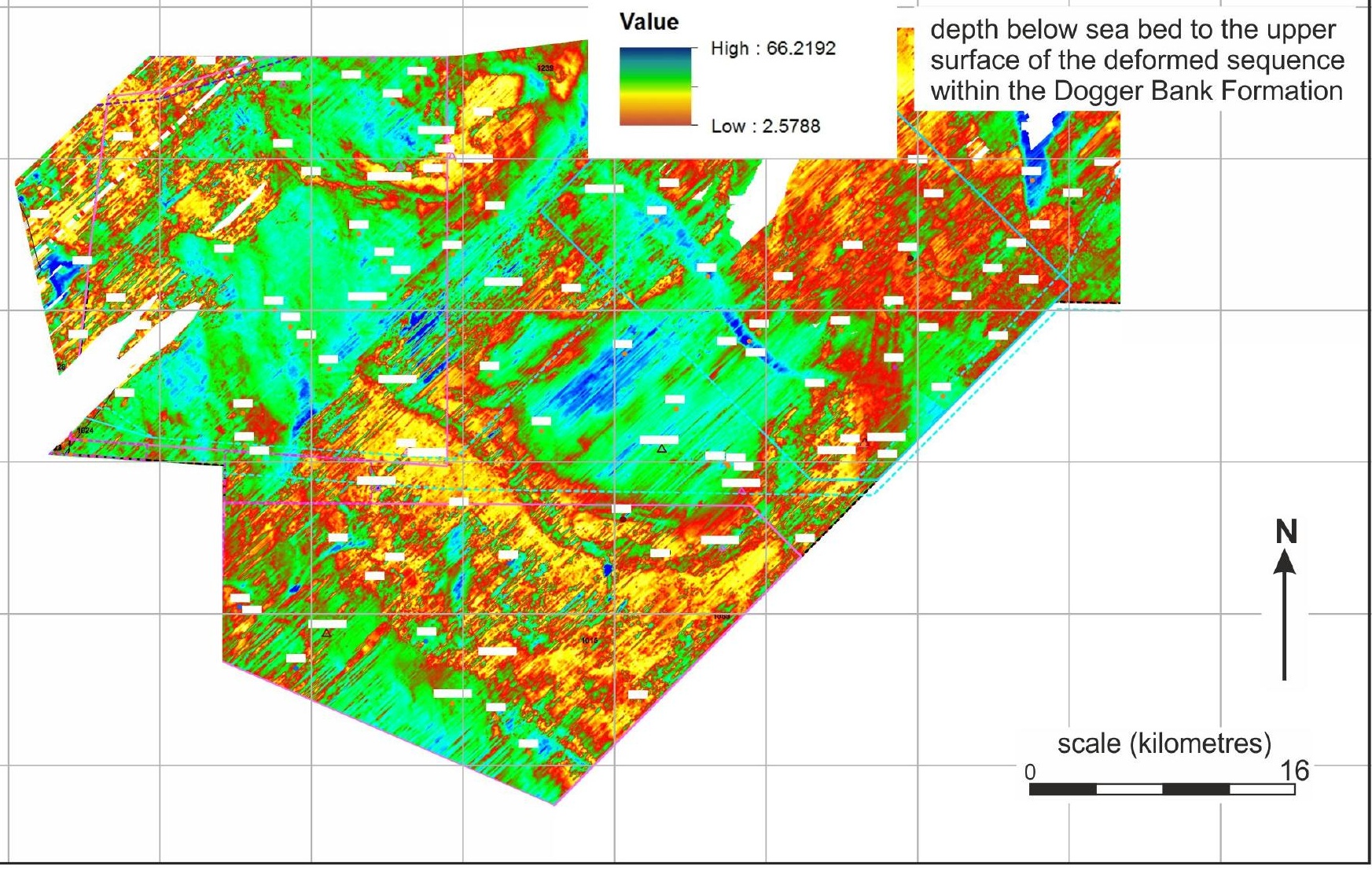

(b) 


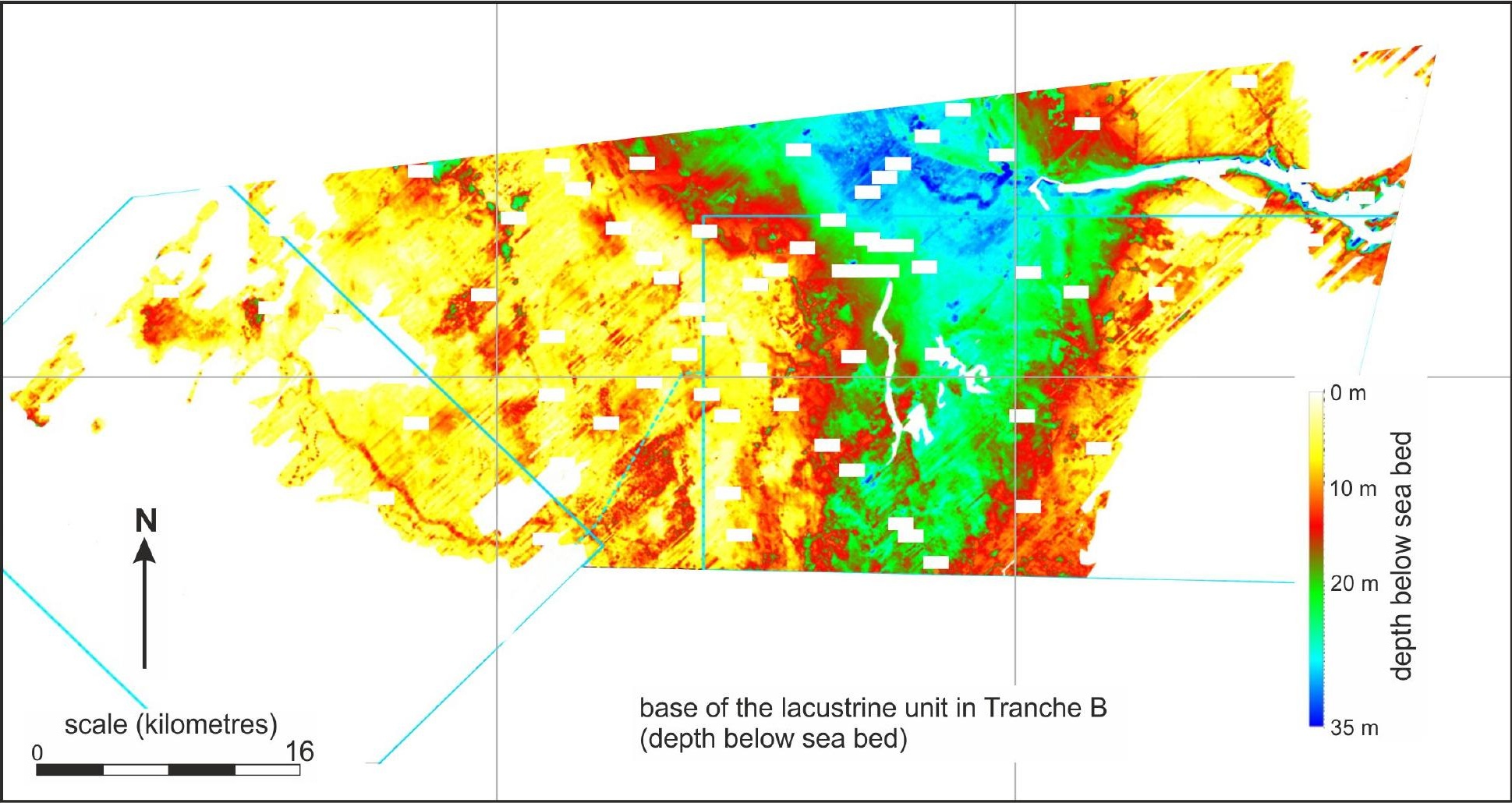

